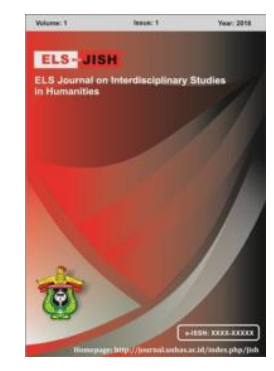

ELS-JISH

ELS Journal on Interdisciplinary Studies on Humanities

Volume 3 Issue 1, 2020

ISSN (print) : 2621-0843

ISSN (online) : 2621-0835

Homepage : http://journal.unhas.ac.id/index.php/jish

\title{
The Use of Skit Technique in Enhancing the Students' Speaking Ability
}

\author{
Andi Patmasari ${ }^{1}$ \\ 1apatmasari@gmail.com
}

\begin{abstract}
This research intended to prove whether the use of skit technique enhanced the students' speaking ability or not. This research employed quasi-experimental research design with the non-equivalent control group design. The population of this research was the second year students of senior high school that consisted of 260 students. This research used cluster random sampling technique. From nine classes, two classes were taken as a sample of the research. One class was chosen as the experimental class and another one as the control class. The total sample consisted of 72 students. In order to answer the research question, the instrument of this research was a speaking test. There are some types of oral tests, but this research used a picture story. The result of data analysis showed that the rate percentage and frequency of the post-test score was higher than the rate percentage and frequency of the pretest score. In pretest, the value of $t$-test (0.34) was lower than the value of $t$-table (1.980). While in post-test, the t-test value (2.83) was higher than the t-table value (1.980). Based on these findings, it can be inferred that the skit technique significantly enhanced the students' speaking ability.
\end{abstract}

Keywords: Skit, Drama, Speaking Ability.

How to cite: Patmasari, A. (2020). The use of skit technique in enhancing the students' speaking ability. ELS Journal on Interdisciplinary Studies in Humanities, 3(1), 1-9. DOI: http://dx.doi.org/10.34050/els-jish.v3i1.9011

\section{Introduction}

In learning English, speaking is one of the important skills that should be mastered by the students. Its success is measured in terms of the ability to carry out a conversation that involves producing, receiving, and processing information. By mastering speaking, students can carry out conversation with others, give the ideas, and exchange the information. Hence, in speaking class, the students should work as much as possible on their own, talk to one another directly and think the medium of the teacher. Prihandoko identified that precious information about technical capabilities and English could be elaborated into training modules to fit out the community, especially students (Prihandoko, Tembang, Marpaung, \& Rahman, 2019). Accordingly, it is necessary for students to master an attractive technique, namely skit or drama, to enhance speaking skills. 
"Speaking as an instance of use is part of a reciprocal exchange in which both reception and production play a part. It involves both receptive and productive participation" (Jabu, 2008). Widdowson (1985) further explained, "The act of speaking normally in the course of natural communicative interaction involves not only the use of gesture, the movement of the muscles of the face, and indeed of the whole body."

According to Brown and Yule (1983), "One of the aims of the teaching of English as a second or foreign language is to make the learners able to communicate information effectively in spoken English." Due to the statement, the teachers should have a teaching technique to help the students and solve the problems of the students in learning English. They should be able to arrange their assignment expertly. They are demanded to motivate the students to learn English well and make the students be competent users of English in communicating with others. For example, in speaking class, the students are expected to be able to do and realize the speech, such as opening, defending, closing the conversation, and asking for help.

In learning to speak, the students often find problems. From the observation, it is encountered that the students were lack of vocabulary. It made their speaking ability low. Rivers (1981) argued, "The teacher needs to allow the students to practice the speaking skill. Whenever they want to speak, they always feel afraid of making mistakes." Related to the statement, teaching technique becomes one of the essential points in teaching and learning activities. The teaching technique is related to the method being used by the teacher on the teaching and learning activities.

A skit is a technique that can be applied in teaching speaking. The skit is one of the drama types. It is defined as a technique to communicate or convey the intended meaning which involves a wide range of activities. Shiue (2006) stated, "Skit (a short humorous acted-out drama) in the classroom means honing thinking skills, increasing comprehension, bringing the written word to life and fun." In addition, it requires cooperation, communication and creativity.

Skit is commonly used in EFL classes for developing communicative competence and oral language skills. Skit or drama is not the words but the situation in which the words are delivered that matters. It can reinforce a need to speak by drawing learners' attention to focus on creating dramatic situations. Most instructor agree that skit is a standard classroom technique which has 'long been recognized as a valuable and valid means of mastering a language' Hines (1973).

The benefits of drama to speaking development are extensively acknowledged. According to Hamilton and McLeod (1993), "Drama is beneficial especially to speaking development." Wessels (1987) added, "Drama can reinforce a need to speak by drawing learners' attention to focus." Other aspects are also clarified by Mattevi (2005) and Makita-Discekici (1999). They assumed that the use of drama in an English class not only enables English teachers to deliver the English language in an active and communicative way but also to create realistic situations. 
Furthermore, Dougil (1987) and Taylor (2000) stated that drama techniques could satisfy the needs of language learning, create motivation and enhance confidence in learning a language. Skit can draw learners' attention to focus on creating dramatic situations, dialogues, role plays, or problem solving exercises. It is also great fun. All these views seem to confirm the benefits of drama and skit to enhance the students' speaking ability.

Based on the background, the research question examined in this research was "Does the use of skit technique enhance the students' speaking ability?"

\section{Method}

This research employed quasi-experimental research design with the nonequivalent control group design. The non-equivalent control group design looks very much like the pretest and post-test control group design. The only difference is that it involves random assignment of intact groups to treatments, not random assignment of individuals. Furthermore, Gay, Mills, and Airasian (2006) stated, "In non-equivalent control group design, two (or more) treatment groups are pretested, administered a treatment, and posttested." This design takes the following form:

$\begin{array}{lll}\mathrm{O} & \mathrm{X} 1 & \mathrm{O} \\ \mathrm{O} & \mathrm{X} 2 & \mathrm{O}\end{array}$

Note:

$\mathrm{O}=$ test, pretest, or posttest

$\mathrm{X} 1=$ unusual treatment

$\mathrm{X} 2=$ control treatment

(Gay, Mills, and Airasian, 2006:255)

In terms of functions, two other terms for variables that were frequently mentioned in this research were independent and dependent variables. The independent variable in this research was the use of skit technique and the dependent variable was the students' speaking ability.

The population of this research was the second year students of senior high school that consisted of 260 students. This research used cluster random sampling technique. From nine classes, two classes were taken as a sample of the research. One class was chosen as the experimental class and another one as the control class. The total sample consisted of 72 students.

In order to answer the research question, the instrument of this research was speaking test. There are some types of oral tests, but this research used a picture story. The students were given pictures or sequence of pictures and they might look at the pictures for two until three minutes before the test started. Then, they were asked to tell a story (narrative story) based on the pictures given. The tests administered before and after exposing students to the use of skit technique. The pretest was intended to see the students' prior knowledge on speaking before giving treatment and the post-test administered to know the students' speaking ability after the treatment using skit technique. 


\section{Findings}

In collecting the data, the researcher administered tests; pretest and posttest. Pretest was given before the treatment and post-test was given after the treatment. The results of the tests can be seen as in the following.

\subsection{The Rate Percentage and Frequency of the Students' Score}

The rate percentage and frequency of the students' score of experimental and control classes were presented in the following tables.

Table 1. The Rate Percentage and Frequency of the Students' Score in

Experimental Class

\begin{tabular}{rlrrrrr}
\hline \multirow{2}{*}{ No } & Classification & \multicolumn{2}{c}{ Pretest } & \multicolumn{2}{c}{ Post-test } \\
\cline { 3 - 7 } & Frequency & $\begin{array}{c}\text { Percentage } \\
(\%)\end{array}$ & Frequency & $\begin{array}{c}\text { Percentage } \\
(\%)\end{array}$ \\
\hline 1 & Excellent & 0 & $0 \%$ & 0 & $0 \%$ \\
\hline 2 & Very good & 2 & $5.6 \%$ & 9 & $25.0 \%$ \\
\hline 3 & Good & 4 & $11.1 \%$ & 10 & $27.8 \%$ \\
\hline 4 & Fairly good & 11 & $30.6 \%$ & 14 & $38.9 \%$ \\
\hline 5 & Fair & 7 & $19.4 \%$ & 2 & $5.5 \%$ \\
\hline 6 & Poor & 12 & $33.3 \%$ & 1 & $2.8 \%$ \\
\hline 7 & Very poor & 0 & $0 \%$ & 0 & $0 \%$ \\
\hline & Total & $\mathbf{3 6}$ & $\mathbf{1 0 0} \%$ & $\mathbf{3 6}$ & $\mathbf{1 0 0 \%}$ \\
\hline
\end{tabular}

Table 1 shows that before the treatment given to the students in experimental class, only 2 students (5.6\%) got "Very good", 4 students $(11.1 \%)$ got "Good", 11 students (30.6\%) got "Fairly good", 7 students (19.4\%) got "Fair", and 12 students (33.3\%) got "Poor". And after the treatment was given, there were 9 students $(25.0 \%)$ got "Very good", 10 students $(27.8 \%)$ got "Good", 14 students (38.9\%) got "Fairly good", 2 students (5.5\%) got "Fair", and 1 student (2.8\%) got "Poor". The rate percentage and frequency of the post-test score was higher than the rate percentage and frequency of the pretest score.

Table 2. The Rate Percentage and Frequency of the Students' Score in Control Class

\begin{tabular}{clcccc}
\hline \multirow{2}{*}{ No } & Classification & \multicolumn{2}{c}{ Pretest } & \multicolumn{2}{c}{ Post-test } \\
\cline { 3 - 6 } & Frequency & $\begin{array}{c}\text { Percentage } \\
(\%)\end{array}$ & Frequency & $\begin{array}{c}\text { Percentage } \\
(\%)\end{array}$ \\
\hline 1 & Excellent & 0 & $0 \%$ & 0 & $0 \%$ \\
\hline 2 & Very good & 2 & $5.6 \%$ & 4 & $11.1 \%$ \\
\hline 3 & Good & 3 & $8.3 \%$ & 9 & $25.0 \%$ \\
\hline 4 & Fairly good & 12 & $33.3 \%$ & 9 & $25.0 \%$ \\
\hline 5 & Fair & 6 & $16.7 \%$ & 5 & $13.9 \%$ \\
\hline 6 & Poor & 13 & $36.1 \%$ & 9 & $25.0 \%$ \\
\hline 7 & Very poor & 0 & $0 \%$ & 0 & $0 \%$ \\
\hline & Total & $\mathbf{3 6}$ & $\mathbf{1 0 0} \%$ & $\mathbf{3 6}$ & $\mathbf{1 0 0} \%$ \\
\hline
\end{tabular}


Out of 36 students in control class, there were 2 students $(5.6 \%)$ got "Very good" in pretest, three students (8.3\%) got "Good", 12 students (33.3\%) got "Fairly good", 6 students (16.7\%) got "Fair", and 13 students (36.1\%) got "Poor." On the post-test, there were 4 students $(11.1 \%)$ got "Very good", 9 students (25.0\%) got "Good", 9 students (25.0\%) got "Fairly good", 5 students $(13.9 \%)$ got "Fair", and 9 students $(25.0 \%)$ got "Poor". The rate percentage and frequency of the post-test score was higher than the rate percentage and frequency in the pretest score. But compare to the experimental class, the rate percentage and frequency of the experimental class was higher than the control class.

\subsection{The Mean Score and Standard Deviation of the Pre-Test Score of Experimental and Control Classes}

After calculating the data of both classes, the mean score and standard deviation of the pretest score of both classes were presented the following table.

Table 3. The Mean Score and Standard Deviation of the Pre-Test Score

\begin{tabular}{lcc}
\multicolumn{1}{c}{ Class } & Mean score & Standard Deviation \\
\hline Experimental & 64.81 & 11.98 \\
\hline Control & 63.83 & 11.35 \\
\hline
\end{tabular}

Table 3 shows that the mean score of the students in the experimental class was 64.81 and the standard deviation was 11.98 , while in the control class, the mean score was 63.83 and the standard deviation was 11.35.

\subsection{The Mean Score and Standard Deviation of the Post-Test Score of Experimental and Control Classes}

After calculating the data of both classes, the mean score and standard deviation of the post-test score of both classes were presented the following table.

Table 4. The Mean Score and Standard Deviation of the Post-Test Score

\begin{tabular}{lcc}
\multicolumn{1}{c}{ Class } & Mean score & Standard Deviation \\
\hline Experimental & 77.44 & 10.43 \\
\hline Control & 69.44 & 12.72 \\
\hline
\end{tabular}

Table 4 shows that the mean score of the students in the experimental class was 77.44 and the standard deviation was 10.43 , while in the control class, the mean score was 69.44 and the standard deviation was 12.72 .

\subsection{The T-Test Value of Students' Pretest and Post-Test}

In order to know whether or not the mean scores of both classes are significantly different at the level of significance 0.05 with the degrees of freedom $(\mathrm{df})=(\mathrm{n} 1+\mathrm{n} 2-2)$, t-test analysis for independent sample was employed. The following tables show the result of the calculation. 
Table 5. The T-test Value of the Students' Pretest

\begin{tabular}{ccc}
\hline Variable & T-test & T-table \\
\hline Pre-test & 0.34 & 1.980 \\
\hline
\end{tabular}

Table 5 shows that the value of t-test (0.34) was lower than the value of $t-$ table (1.980). Based on this finding, it can be concluded that there was no significant difference between the mean score of the students' pretest from both classes.

Table 6. The T-test Value of the Students' Post-Test

\begin{tabular}{ccc} 
Variable & T-test & T-table \\
\hline Post-test & 2.83 & 1.980 \\
\hline
\end{tabular}

From the data in table 6 , it is clear that the t-test value (2.83) was higher than the t-table value (1.980). Based on this finding, it can be inferred that the difference between the post-test score of both classes was significant, which means that skit technique can significantly enhance the students' speaking ability.

\section{Discussion}

This part deals with the interpretation of the findings. It also includes the explanation of supporting data which have been collected for three weeks.

Before giving the treatment, pretest was given to the students in experimental and control classes. It was intended to identify the students' prior speaking ability. The students were given pictures or sequence of pictures and they might look at the pictures for two until three minutes before the test started. Then, they were asked to tell a story (narrative story) based on the pictures given. The students' speaking performance was recorded. Most of them only told a very short story and still felt shy to speak. They were poor in accuracy because their pronunciation was still influenced by the mother tongue. Besides, they did some errors in grammar and used the wrong vocabulary that caused misunderstanding.

After conducting pretest, the experimental class was given treatment as long as four meetings. The first meeting for the treatment was "Working on a Drama Script". It involved the identification of background knowledge concerning a play which students were required to engage in. In order to make the interaction more meaningful and facilitate the students' acquisition of a language, they needed to know the plot, the characters, and all the elements of drama in the script. The students were divided into some group to discuss about the script. They were asked to analyse the script and read their analysis in front of the class loudly. During the first treatment, the students seemed a little confused to work on the script. Their speaking accuracy and fluency were still poor.

The second meeting was "Modifying the Script". After working on a script which has been prepared, in the second meeting, the students were asked to modify the script. They were asked to sit together with their group, modified the script to be a short humorous drama based on their imagination and creativity, 
and designed a play for themselves. In this meeting, the students' speaking ability experienced a slight increase because they have tried to express their idea and produce their own skit.

The third meeting was "Skit Rehearsal". It was done to make the students' performance would be better and more interesting. Skit rehearsal was designed to elicit students' physical and emotional engagement. In this step, students were assigned to play each character's role. Close monitoring and interruptions were required in this step in order to correct the students' pronunciation and enhance their understanding. Most of the students were interested to express their idea and enjoyed this skit activity.

The fourth meeting was the last meeting for the treatment. It was "Skit Production". This step created opportunities for students to experience life like communication situations. Through a performance, students could exploit facial expressions, intonations, and gesture to convey the intended meaning of each character. It helped them internalize both linguistic and non-linguistic components of speaking ability. While one of some group performed their play of skit, the teacher assessed the group performance. In this step, the students' performance was videotaped. In the fourth meeting, most of the students were stimulated to play and enjoyed the skit production because this activity was really fun for them and they could express theirselves without feeling burdened.

After finishing the treatment of the experimental class, post-test was given to the students in experimental and control classes. This test was used to compare the students' speaking ability before and after the treatment. And also to find out the value of the treatment whether the skit technique enhanced the students' speaking ability or not. The form of the post-test was the same as the pretest, but it was in different pictures. The students were given pictures or sequence of pictures and they might look at the pictures for two until three minutes before the test started. Then, they were asked to tell a story (narrative story) based on the pictures given. Based on the result, the students' speaking ability in experimental class enhanced after giving the treatment. The students' error in grammar and pronunciation decreased and they trained to speak relax and well.

These findings were supported by some researchers who have already done research projects in the field of speaking, skit, drama, and simulation. Shiue (2006) who conducted a research under the title "Using Skit to Motivate CCU Students' Learning English" stated that skit created and performed by students can be a successful supplement to the classroom experience. Syamsinar (2004) found that most of students of SMAN 1 Belawa had favorable interest because most of them agreed with the positive statement and disagreed with the negative ones about learning speaking through drama teaching techniques. Indrawaty (2010) who conducted a research under the title "Minimizing English Pronunciation of the Second Year Students of SMAN 1 Camba by Using Drama Text" concluded that by using drama, students could increase their self confidence, express their feelings, ideas, and thought. Futhermore, Treesye (2002) reported that simulation was an effective technique to encourage students to speak English and also promoted active involvement in learning. In simulation, students could create a realistic environment. From 
the related studies, it can be concluded that drama is one of the best techniques in teaching speaking. There are many types of drama, one of them is skit. This technique is proved to be one of the effective media in enhancing the students' speaking ability.

\section{Conclusions}

In both classes, the experimental and control classes, the rate percentage and frequency of the post-test score was higher than the rate percentage and frequency of the pretest score. It means that the students' speaking ability in both classes has increased. However, in comparison with the experimental class, the rate percentage and frequency of the experimental class was higher than the control class.

In pretest, the mean score of the students in experimental class was 64.81, while in control class, the mean score was 63.83. In post-test, the mean score of the students in experimental class was 77.44 and in control class, the mean score was 69.44. It means that the students' speaking ability in both classes has increased. But compare to the experimental class, the mean score of the students in the experimental class was higher than the control class.

In pretest, the value of t-test $(0.34)$ was lower than the value of t-table (1.980). Based on this finding, it can be concluded that there was no significant difference between the mean score of the students' pretest from both classes, which means that the students' speaking ability in both classes were at the same level before the treatment given. While in post-test, the t-test value (2.83) was higher than the t-table value (1.980). Based on this finding, it can be inferred that the difference between the post-test score of both classes was significant, which means that skit technique could significantly enhance the students' speaking ability.

Considering the result of this research, it is suggested for the English teacher to be more creative and to enrich their teaching materials. They can apply skit to stimulate the students' attention and motivate them in learning English. For the future researchers, the duration of the treatment in the present research was rather short, so further research with longer intervention should be carried out.

\section{References}

Brown, G. and Yule, G. (1983). Teaching the spoken language. Cambridge: Cambridge University Press.

Dougil, J. (1987). Drama activities for language learning. London: Macmilian.

Gay, L. R., Mills, G. E., and Airasian, P. (2006). Education research: Competencies for analysis and applications. New Jersey: Merrill Prentice Hall.

Hamilton, J. and Mcleod, A. (1993). Drama in the language classroom. London: Center for Information on Language Teaching and Research.

Hines, M. (1973). Skits in English as a second language. New York: Regents. 
Indrawaty, I. (2010). Minimizing English Pronunciation of the Second Year Students of SMAN 1 Camba by Using Drama Text (Unpublished thesis). State University of Makassar, Makassar.

Jabu, B. (2008). English language testing. Makassar: The UNM Publisher.

Makita-Discekici, Y. (1999). Creative skit activity in Japanese language classroom. Canadian Modern Language Review. 55(3), 404-412.

Mattevi, Y. (2005). Using drama in the classroom: the educational values theatre in second language acquisition. Retrieved from: http://proquest.umi.com/pqdwebndex

Prihandoko, L. A., Tembang, Y., Marpaung, D. N., \& Rahman, F. (2019). English Language Competence for Tourism Sector in Supporting Socioeconomic Development in Merauke: A Survey Study. IOP Conference Series: Earth and Environmental Science, 343(1). https://doi.org/10.1088/1755-1315/343/1/012170

Rivers, W. M. (1981). Teaching Foreign-language Skills. Chicago: The University of Chicago Press.

Shiue, C. (2006). Using Skits to Motivate CCU Students Learning English. China: Chinese Culture University.

Syamsinar. (2004). Developing Speaking Ability of the Second Year Students of SMAN 1 Belawa through Drama (Unpublished thesis). State University of Makassar, Makassar.

Taylor, P. (2000). The drama classroom: Action, reflection, transformation. London: Routledge Falmer.

Treesye, S. M. (2002). Teaching speaking by using simulation to the second year students of SLTP Katolik Rajawali Makassar. (Unpublished thesis). State University of Makassar, Makassar.

Wessels, C. (1987). Drama. Oxford: Oxford University Press.

Widdowson, H. G. (1985). Teaching Language as Communication. Oxford: Oxford University Press. 